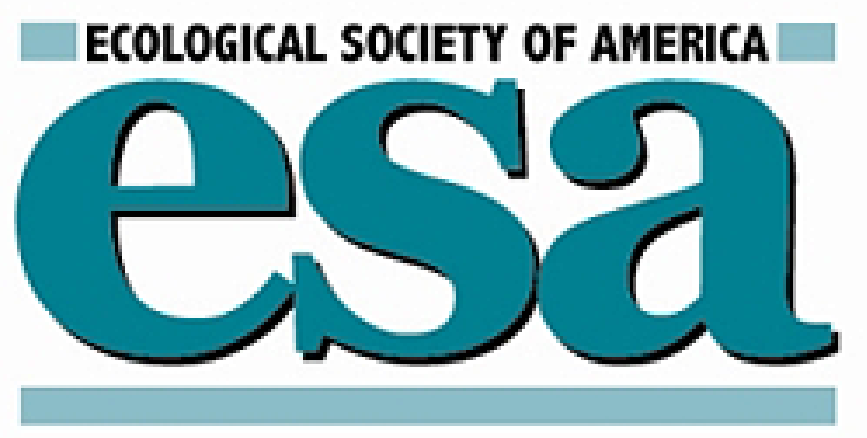

Algal Periphyton Growth on Nutrient-Diffusing Substrates: An in situ Bioassay Author(s): G. Winfield Fairchild, Rex L. Lowe and William B. Richardson

Source: Ecology, Vol. 66, No. 2 (Apr., 1985), pp. 465-472

Published by: Ecological Society of America

Stable URL: http://www.jstor.org/stable/1940395

Accessed: 13/03/2014 09:13

Your use of the JSTOR archive indicates your acceptance of the Terms \& Conditions of Use, available at http://www.jstor.org/page/info/about/policies/terms.jsp

JSTOR is a not-for-profit service that helps scholars, researchers, and students discover, use, and build upon a wide range of content in a trusted digital archive. We use information technology and tools to increase productivity and facilitate new forms of scholarship. For more information about JSTOR, please contact support@jstor.org. 


\title{
ALGAL PERIPHYTON GROWTH ON NUTRIENT-DIFFUSING SUBSTRATES: AN IN SITU BIOASSAY ${ }^{1}$
}

\author{
G. WINFIELD FAIRCHILD \\ Biology Department, West Chester University, West Chester, Pennsylvania 19383 USA
}

REX L. LowE ${ }^{2}$

Center for Environmental Studies, Virginia Polytechnic Institute and State University, Blacksburg, Virginia 24061 USA

AND

WILLIAM B. RICHARDSON ${ }^{3}$

Biology Department, Central Michigan University, Mount Pleasant, Michigan 48859 USA

\begin{abstract}
Differences in nutrient limitation for dominant species within an algal periphyton community were determined using additions of $\mathrm{N}$ and $\mathrm{P}$ supplied by nutrient-diffusing artificial substrates. Sealed clay flowerpots were filled with $2 \%$ agar and one of nine nutrient treatments (all combinations of $\mathrm{K}_{2} \mathrm{HPO}_{4}$ at $0.0,0.05$, and $0.5 \mathrm{~mol} / \mathrm{L}$ with $\mathrm{NaNO}_{3}$ at $0.0,0.05$, and $0.5 \mathrm{~mol} / \mathrm{L}$ ). The pots were submerged at $0.5 \mathrm{~m}$ depth in Douglas Lake, Michigan, and diffused $\mathrm{N}$ and $\mathrm{P}$ to their outer surfaces in proportion to internal concentrations. After $51 \mathrm{~d}$ the pots were scraped and analyzed for attached algae.

Total algal biomass as chlorophyll $a$ on the pots ranged from $0.17 \pm 0.02(\mathrm{SE}) \mu \mathrm{g} / \mathrm{cm}^{2}$ for pots without added nutrients to $15.7 \pm 2.0 \mu \mathrm{g} / \mathrm{cm}^{2}$ for pots with $\mathrm{K}_{2} \mathrm{HPO}_{4}$ at $0.05 \mathrm{~mol} / \mathrm{L}$ and $\mathrm{NaNO}_{3}$ at $0.5 \mathrm{~mol} / \mathrm{L}$. Chlorophyll $a$ on pots containing just $\mathrm{P}(0.05,0.5 \mathrm{~mol} / \mathrm{L})$ increased 6 - to 10 -fold over controls. The diatoms Epithemia adnata and Rhopalodia gibba and the blue-green alga Anabaena increased significantly on the P-only pots; these species are suspected of $\mathrm{N}$-fixing capability. Chlorophyll $a$ on pots containing just $\mathrm{N}(0.05,0.5 \mathrm{~mol} / \mathrm{L})$ increased $1.5-$ to 2 -fold, though this increase was nonsignificant; Achnanthes minutissima, Gomphonema tenellum, and Cocconeis placentula showed enhanced growth on these pots.

Combinations of $\mathrm{N}$ and $\mathrm{P}$ caused heavy growths of the filamentous alga Stigeoclonium tenue. Naviculoid diatoms were also most abundant on the $\mathrm{N}+\mathrm{P}$ pots.

Average nutrient levels in Douglas Lake during the study were: $\mathrm{NH}_{3}, 2.02 \mu \mathrm{mol} / \mathrm{L} ; \mathrm{NO}_{3}, 0.44$ $\mu \mathrm{mol} / \mathrm{L} ;$ and $\mathrm{PO}_{4}, 0.06 \mu \mathrm{mol} / \mathrm{L}$. The low ambient concentrations of both $\mathrm{N}$ and $\mathrm{P}$, together with results of the periphyton bioassay, indicate that the two nutrients may jointly limit overall growth, and that the form of growth limitation differs by species within the periphyton community.
\end{abstract}

Key words: algal growth; bioassay; nitrogen; nitrogen fixation; nutrient limitation; periphyton; phosphorus.

\section{INTRODUCTION}

Algal species are known to respond to certain nutrients as noninteractive essential resources (Tilman 1982, Tilman et al. 1982), and their growth is thus limited by the nutrient in least supply relative to needs (Droop 1974, Rhee 1978). Phosphate has been demonstrated both on theoretical grounds (Schindler 1977) and through numerous field studies to directly control algal abundance in many lakes. Nitrogen limitation is also common (Storch and Dietrich 1979, Kratzer and Brezonik 1981, Zevenboom et al. 1982).

A variety of bioassay procedures have used algal growth enhancement in response to added nutrients to identify the form of nutrient limitation. Such bioassays have included both laboratory and in situ lake studies (Glass 1973, Middlebrooks et al. 1976, Marvan et al.

\footnotetext{
1 Manuscript received 7 November 1983; revised 26 March 1984; accepted 4 April 1984.

${ }^{2}$ Present address: Biology Department, Bowling Green State University, Bowling Green, Ohio 43403 USA.

${ }^{3}$ Present address: Department of Zoology, University of Oklahoma, Norman, Oklahoma 73019 USA.
}

1979). In situ methods have most commonly used closed plastic or glass containers suspended in the water column (Schelske et al. 1975, Komarkova 1979) or open tubes reaching from the surface into the lake sediments (Moss 1981).

Bioassay procedures, however, can give varying interpretations of nutrient limitation in a given lake. Gerhart and Likens (1975), who compared four methods of predicting phytoplankton response to $\mathrm{N}$ and $\mathrm{P}$ in Mirror Lake, New Hampshire, USA, found that shortterm C- 14 bioassays gave misleading results compared to other methods used. Although increases in algal biomass were consistent for both their chemostat and in situ bag enrichment procedures, species composition was highly sensitive to artificial conditions imposed and thus was of little value for interpreting nutrient limitation results.

Although most studies have involved phytoplankton, algal periphyton growth may also be used to assess the form of nutrient limitation, as shown by Wuhrmann and Eichenberger (1974), Stockner and Shortreed (1978), Marcus (1980), Krewer and Holm (1982) 
and Peterson et al. (1983) for streams, and Sladeckova (1979) for lakes. Periphyton, because they are attached, are especially useful as biological indicators of point sources of nutrients in lakes (Kuhn et al. 1981). Localized supplies of particular ions from natural springs, influent streams, or sewage outfalls, for example, may have little impact upon the water chemistry or phytoplankton of a lake. but may cause identifiable changes in periphyton attached to nearby substrates (Stevenson and Stoermer 1982).

The research described here utilized artificial substrates that act as point sources of nutrients. Clay flowerpots, when filled with specified ions, sealed, and placed in situ, slowly release the ions over many weeks and promote the establishment of periphyton communities on their outer surfaces according to the particular ions supplied. Chapman and Craigie (1977) and Harlin and Thorne-Miller (1981) have used a similar method in studying growth responses of marine algae to added nutrients. We examined the effects upon algal periphyton in Douglas Lake, Michigan, of supplying $\mathrm{N}$ and $\mathrm{P}$ together in varying relative amounts. We were able to describe overall algal growth and to identify those indicator species that became dominant in response to particular nutrient additions. The method is thus an in situ bioassay of nutrient limitation using periphyton. Our data were further used in an evaluation of Tilman's (1982) model predicting growth response to essential resources.

\section{Materials and Methods}

\section{Nutrient diffusion rates}

Clay flowerpots (outside diameter $=8.8 \mathrm{~cm}$, height $=$ $8.0 \mathrm{~cm}$ ) were first soaked in deionized water for $3 \mathrm{~d}$, and dried. A plastic Petri dish was attached to the large opening of each pot with silicon adhesive, creating an internal chamber of volume $245 \mathrm{~cm}^{3}$. A hot agar solution $(2 \%)$ containing one of four nutrient treatments $\left(\mathrm{K}_{2} \mathrm{HPO}_{4}, 0.05\right.$ and $0.5 \mathrm{~mol} / \mathrm{L} ; \mathrm{NaNO}_{3}, 0.05$ and 0.5 $\mathrm{mol} / \mathrm{L}$ ) was then poured through the smaller aperture of each pot; each treatment was poured into three pots $(n=12)$. Because the agar was partially absorbed into the clay walls, $300 \mathrm{~cm}^{3}$ could be poured into each pot. Therefore, estimated nutrient contents per pot for the four treatments were $15 \mathrm{mmol}$ and $150 \mathrm{mmol} \mathrm{K}_{2} \mathrm{HPO}_{4}$, and $15 \mathrm{mmol}$ and $150 \mathrm{mmol} \mathrm{NaNO}_{3}$, respectively. The smaller aperture of each pot was closed with a number 000 neoprene stopper.

After the agar had gelled, each pot was placed in a widemouth 4-L glass jar with $1.5 \mathrm{~L}$ of deionized water. The water was sampled for released nutrients and replaced with $1.5 \mathrm{~L}$ new deionized water every $24 \mathrm{~h}$ for 23 d. Room temperatures during this time were recorded daily using a max-min thermometer. Daily mean estimates $(=[$ maximum + minimum $] / 2)$ fluctuated irregularly between $17.8^{\circ}$ and $25.3^{\circ} \mathrm{C}$, averaging $20.8^{\circ}$ $\left(\mathrm{SD}=2.0^{\circ}\right)$. Each day's 12 nutrient samples were stored frozen in acid-washed polyethylene bottles. Daily re- lease rates of $\mathrm{NO}_{3}$ and $\mathrm{PO}_{4}$ were determined for both $\mathrm{N}$ and $\mathrm{P}$ pots on days $1,2,3,6,9,12,15,18,21$, and 23 using a Technicon II Autoanalyzer.

At the end of the experiment, the Petri dish was removed from each pot and the agar scraped from the inner chamber. These agar samples were heated, immediately diluted $1000 \times$ with deionized water, and frozen. Concentrations of $\mathrm{NO}_{3}-\mathrm{N}$ were determined for $\mathrm{N}$ pots. Both $\mathrm{PO}_{4}-\mathrm{P}$ and total $\mathrm{P}$ were measured for $\mathrm{P}$ pots. Amounts remaining in the walls of the pots were not measured.

\section{In situ periphyton study}

Thirty-six pots were sealed with glass Petri dishes, and a single-holed number 10 neoprene stopper with a $15-\mathrm{cm}$ length of wooden dowel was glued to the bottom of each Petri dish. The pots were filled with $2 \%$ agar and one of nine nutrient treatments, representing combinations of $\mathrm{P}$ (as $\mathrm{K}_{2} \mathrm{HPO}_{4}$ at 0.0 , 0.05, or 0.5 $\mathrm{mol} / \mathrm{L}$ ) and $\mathrm{N}$ (as $\mathrm{NaNO}_{3}$ at $0.0,0.05$, or $0.5 \mathrm{~mol} / \mathrm{L}$ ) in a complete factorial design. Each of the nine nutrient treatments was administered to four replicate pots.

The smaller aperture of each pot was then closed with a number 000 neoprene stopper containing a thumbtack, color-coded to denote treatment type. After the agar had gelled, the 36 substrates (pots) were placed $0.5 \mathrm{~m}$ apart in a grid at $0.45-0.55 \mathrm{~m}$ depth in a uniformly sandy portion of South Fishtail Bay in Douglas Lake, Michigan. The dowel of each substrate was pushed into the sand to the base of the large stopper, the flowerpot itself remaining perched $2-3 \mathrm{~cm}$ above the sand. One pot of each treatment was assigned to each of the four rows of the grid. Placement location within rows was determined using a random numbers table. Rows were situated parallel to the shore, 10-15 $m$ from the water's edge.

The substrates were set out on 7 June 1982 and collected $51 \mathrm{~d}$ later for determination of chlorophyll $a$ and enumeration of algal periphyton. In sampling, a plastic 400-mL beaker was placed over each substrate, fitting snugly against the expanded lip of the flowerpot. The beaker thus enclosed $138 \mathrm{~cm}^{2}$ of pot surface and $255 \mathrm{~mL}$ of surrounding water. The substrate and beaker were then pulled from the sand, inverted underwater, and transported to a nearby rowboat. Surrounding water in each sample and any organisms dislodged from the enclosed pot surface were placed in a $1-\mathrm{L}$ widemouth jar. The pot surface was then cleaned with a knife blade and a hard-bristled toothbrush, and rinsed with deionized water, which was also added to the sample jar.

The sample was transferred to a $1-\mathrm{L}$ graduated cylinder and adjusted to $500 \mathrm{~mL}$ with deionized water. The cylinder was shaken well, and a $20-\mathrm{mL}(4 \%)$ aliquot immediately removed using a wide-bore pipet for chlorophyll $a$ analysis. A second 20-mL aliquot was preserved for periphyton counts by adding $2 \mathrm{ml}$ glutaraldehyde.

Chlorophyll $a$ samples were filtered (Millipore, 0.45 

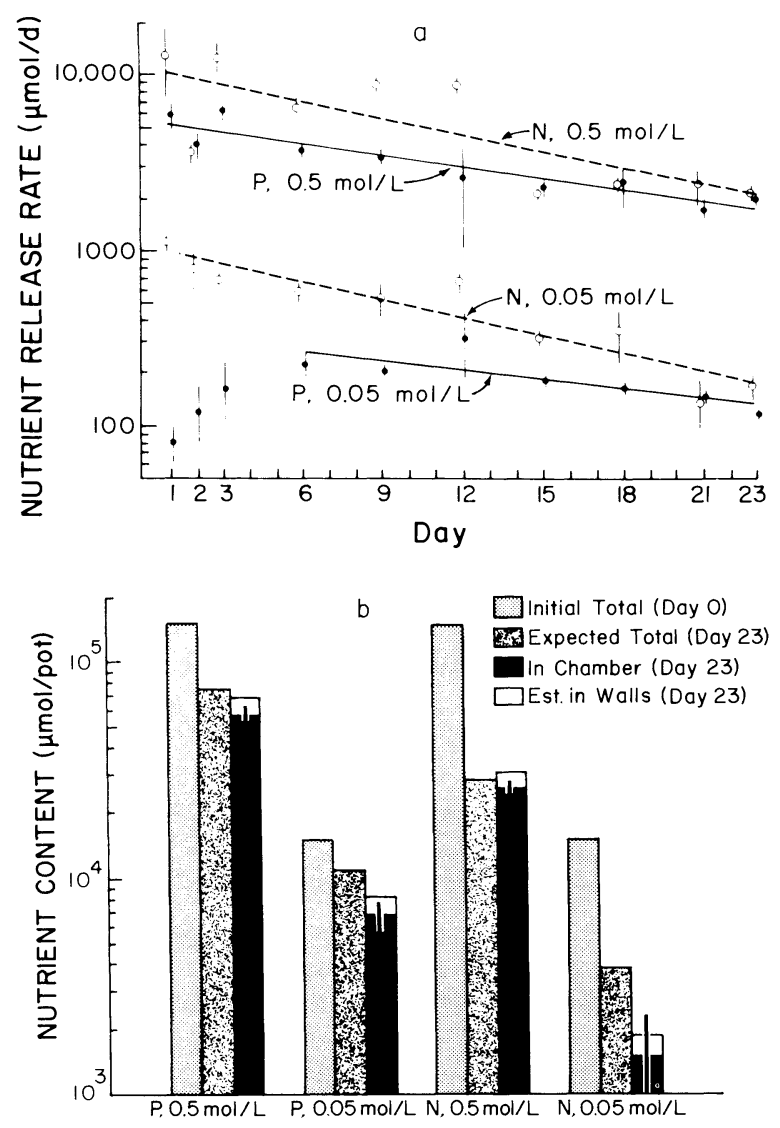

FIG. 1. (a) Average release rates $(R R)(\bar{x}+\mathrm{SE})$ from three pots of each of four nutrient treatments. The data were fit with the function $\ln (R R)=a-b(\mathrm{DAYS})$. The regression for pots with phosphorus at $0.05 \mathrm{~mol} / \mathrm{L}$ used data beginning on day 6 ( $n=7$ dates); for the other three treatments, average values for all 10 sampling dates were used. For $\mathrm{N}$ at $0.5 \mathrm{~mol} / \mathrm{L}$ : $\ln (R R)=9.31-0.07$ (DAYS) $r^{2}=0.59, s_{b}=0.02, F_{1.8}=$ 11.7; for $\mathrm{P}$ at $0.5 \mathrm{~mol} / \mathrm{L}: \ln (R R)=8.63-0.05(\mathrm{DAYS}), r^{2}=$ $0.87, s_{h}=0.01, F_{1.8}=53.3 ;$ for $\mathrm{N}$ at $0.05 \mathrm{~mol} / \mathrm{L}: \ln (R R)=$ $7.01-0.08$ (DAYS), $r^{2}=0.86, s_{h}=0.01, F_{1.8}=49.3$; for $\mathrm{P}$ at $0.05 \mathrm{~mol} / \mathrm{L}: \ln (R R)=5.83-0.04(\mathrm{DAYS}), r^{2}=0.62, s_{b}=$ $0.01, F_{1.5}=8.3$. (b) Mean ( \pm SE) amounts of $\mathrm{N}\left(\right.$ as $\left.\mathrm{NO}_{3}\right)$ and total $\mathrm{P}$ measured on days 0 and 23 in the $245-\mathrm{cm}^{3}$ internal chamber and amounts estimated for the clay walls $\left(55 \mathrm{~cm}^{3}\right)$, compared to the expected amounts remaining as determined by summing the daily losses predicted by the four equations in (a).

$\mu \mathrm{m})$, extracted in $90 \%$ buffered acetone, and analyzed after $24 \mathrm{~h}$ using a Turner 111 fluorometer. Chlorophyll $a$ values were corrected for the presence of phaeopigments (Holm-Hansen et al. 1965) and expressed as micrograms per square centimetre of pot surface.

Algal densities were estimated and generic determinations made using a Palmer-Maloney $(0.1 \mathrm{~mL})$ nannoplankton counting chamber at $450 \times$. Species identifications of the dominant taxa were made from wet mounts for the soft-bodied algae or from permanent Hyrax $^{\circledR}$ mounts (Patrick and Reimer 1966) for the diatoms. The volume of subsample analyzed was

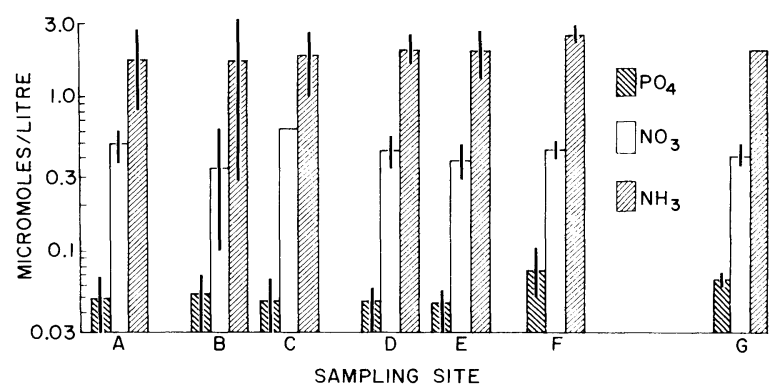

FIG. 2. Mean ( \pm SE) ambient concentrations of $\mathrm{PO}_{4}, \mathrm{NO}_{3}$, and $\mathrm{NH}_{3}$ at each of seven sites (A-G) along a 40-m transect through the grid of artificial substrates. Site B was in the flowerpot grid. The bar diagrams for each site are spaced to approximate the relative distances between sampling locations.

dependent upon the concentration of cells. No fewer than 450 cells were identified from each subsample and in many instances 1000-3000 cells were examined per subsample.

Biovolume (corrected for cell wall volume but not for vacuole volume) was estimated for 10 individuals of each taxon by assuming their shapes to be geometrically simple and regular. The biovolumes of cells with more complicated shapes (e.g., Epithemia, Gomphonema, and Navicula) were determined from scale drawings. For each taxon, the biovolume per surface area of substrate was calculated with the formula $B=b N(\mathrm{~V} /$ v) $/ S$, where $b=$ biovolume per cell, $N=$ number of cells counted, $V / v=$ the portion of the sample analyzed, and $S=$ surface area of the substrate.

In addition to the 36 samples described, sestonic algae were sampled at four locations within the grid by placing the plastic beaker over a clean pot and retaining the $255 \mathrm{~mL}$ of water collected. Mean values for chlorophyll $a$ and abundances of taxa from these samples were subtracted from each of the 36 sample estimates to eliminate effects of the surrounding water from the data. The corrected values for chlorophyll $a$ presented here were very slightly less than uncorrected values, but correcting did serve to reduce the importance of plankton found in the samples.

Statistical analyses comparing chlorophyll $a$ or algal biovolumes by nutrient treatment were organized according to a two-way ANOVA model, with three levels of each of the stratifying variables $\mathrm{N}$ and $\mathrm{P}$. All comparisons of specific treatments, however, utilized one-way ANOVA. Data were log-transformed where necessary to meet the assumption of homogeneous variances.

\section{Nutrient analysis of Douglas Lake water}

On 13 and 27 July, during the periphyton study, concentrations of $\mathrm{NH}_{3}, \mathrm{NO}_{3}$, and $\mathrm{PO}_{4}$ were determined from samples collected at seven sites designated $A-G$ along a 40-m transect through the flowerpot grid and perpendicular to the shoreline. Samples were taken from 
TABLE 1. Mass of chlorophyll $a\left(\mu \mathrm{g} / \mathrm{cm}^{2}\right)$ and total algal biovolume $\left(10^{6} \mu \mathrm{m}^{3} / \mathrm{cm}^{2}\right)$ that accumulated on submerged pots containing nine combinations of $\mathrm{N}$ and $\mathrm{P}(\bar{x} \pm \mathrm{SE})$.

\begin{tabular}{clccc}
\hline \hline $\begin{array}{c}\text { Phosphorus } \\
\text { concentration } \\
(\mathrm{mol} / \mathrm{L})\end{array}$ & \multicolumn{1}{c}{ Measure } & \multicolumn{3}{c}{ Nitrogen concentration $(\mathrm{mol} / \mathrm{L})$} \\
\cline { 3 - 5 } & Chlorophyll $a\left(\mu \mathrm{g} / \mathrm{cm}^{2}\right)$ & $0.171 \pm 0.020$ & 0.05 & 0.5 \\
\hline 0.0 & Alg. vol. $\left(10^{6} \mu \mathrm{m}^{3} / \mathrm{cm}^{2}\right)$ & $9.26 \pm 2.10$ & $14.68 \pm 1.29$ & $0.340 \pm 0.055$ \\
& Chlorophyll $a\left(\mu \mathrm{g} / \mathrm{cm}^{2}\right)$ & $1.636 \pm 0.528$ & $2.229 \pm 0.228$ & $15.71 \pm 2.033$ \\
0.05 & Alg. vol. $\left(10^{6} \mu \mathrm{m}^{3} / \mathrm{cm}^{2}\right)$ & $29.87 \pm 4.83$ & $419.4 \pm 92.2$ & $1332 . \pm 106.5$ \\
& Chlorophyll $a\left(\mu \mathrm{g} / \mathrm{cm}^{2}\right)$ & $1.054 \pm 0.303$ & $1.497 \pm 0.096$ & $12.65 \pm 1.292$ \\
0.5 & Alg. vol. $\left(10^{6} \mu \mathrm{m}^{3} / \mathrm{cm}^{2}\right)$ & $22.49 \pm 5.65$ & $159.8 \pm 19.2$ & $694.9 \pm 137.5$ \\
& & &
\end{tabular}

both $0.5 \mathrm{~m}$ and $1.0 \mathrm{~m}$ depth at the deeper sites (E-G). Single samples just above the sandy bottom were collected from sites A-D. Site B was located within the flowerpot grid. The weather on both days was calm. Samples were refrigerated, then analyzed within 2-3 d using a Technicon II Autoanalyzer.

\section{RESULTS}

Diffusion rates from the substrates under laboratory conditions varied according to both the type of ion $\left(\mathrm{NO}_{3}\right.$ vs. $\left.\mathrm{PO}_{4}\right)$ and internal concentration (0.05 vs. 0.5 $\mathrm{mol} / \mathrm{L})$. Replicate pots showed similar release patterns, with no consistent differences between pots. Mean release rates generally declined during the 23-d study, showing linear trends on a semi-log plot (Fig. 1a). Diffusion rates from $\mathrm{N}$ pots were initially higher than from $P$ pots of the same concentration. Unlike the other treatments, the $\mathrm{P}$ pots with $0.05 \mathrm{~mol} / \mathrm{L}$ showed increasing leaching rates during days $1-3$. Release rates of $\mathrm{NO}_{3}-\mathrm{N}$ from $\mathrm{P}$ pots and of $\mathrm{PO}_{4}-\mathrm{P}$ from $\mathrm{N}$ pots were not detectable at the dilution levels used, and ions supplied by the pots themselves must have been extremely low, if present, in comparison to ions introduced in the agar solution.

Regression lines were fit to the data from days 1 to 23 using mean daily release rates (RR) for one P treatment $(0.5 / \mathrm{mol} / \mathrm{L})$ and two $\mathrm{N}$ treatments $(0.05$ and 0.5 $\mathrm{mol} / \mathrm{L})$. The regression used for the pots with $\mathrm{P}$ at 0.05 $\mathrm{mol} / \mathrm{L}$ used data beginning on day 6 . The proportion of variation explained $\left(r^{2}\right)$, the standard error of the slope $\left(s_{b}\right)$ and the significance level of the regression are given with each equation (see Fig. 1a).

Nutrients remaining in the agar on day 23 (Fig. 1b) were consistently below amounts predicted by summing daily losses using the equations in Fig. 1a. If the nutrient content of agar absorbed into the clay walls $\left(55 \mathrm{~cm}^{3}\right)$ is assumed to be the same as that of agar in the internal chamber $\left(245 \mathrm{~cm}^{3}\right)$, however, the agreement of their combined values with expected contents is quite good, except for the pots with $\mathrm{N}$ at $0.05 \mathrm{~mol} /$ $\mathrm{L}$, one of which produced an anomalously low estimate. Whereas all $\mathrm{N}$ measured in the agar on day 23 was present as $\mathrm{NO}_{3}-\mathrm{N}$, most of the $\mathrm{P}$ was organically bound, and $\mathrm{PO}_{4}-\mathrm{P}$ represented only $9.9 \%$ and $2.1 \%$ of total $\mathrm{P}$ in the pots with $\mathrm{P}$ at 0.05 and $0.5 \mathrm{~mol} / \mathrm{L}$, re- spectively. The slower release of $\mathrm{PO}_{4}-\mathrm{P}$ may therefore be in part a result of the apparent complexing of the phosphate with the agar.

Differences between the laboratory and Douglas Lake with respect to conditions known to affect diffusion rates (e.g., temperature, current velocity, $\mathrm{pH}$, and external ion concentrations) do not permit precise estimation of release rates in situ. The results indicate, however, that both nutrients were probably available in at least small amounts throughout the field study, and that substrates with higher initial internal nutrient concentrations supplied proportionally higher amounts of these nutrients to their external surfaces.

Concentrations of $\mathrm{NO}_{3}, \mathrm{NH}_{3}$, and $\mathrm{PO}_{4}$ found along the transect through the grid of nutrient-rich substrates differed little by either depth or sampling date. Nutrient release from substrates within the grid apparently did not affect ambient concentrations of either $\mathrm{NO}_{3}$ or $\mathrm{PO}_{4}$ at site $\mathrm{B}$ (Fig. 2). There was thus no evidence of pots chemically affecting neighboring pots within the grid. Concentrations of $\mathrm{PO}_{4}$ along the transect averaged 0.06 $\mu \mathrm{mol} / \mathrm{L}$ while those of $\mathrm{NO}_{3}$ averaged $0.44 \mu \mathrm{mol} / \mathrm{L}$. Concentrations of $\mathrm{NH}_{3}$ were relatively high in comparison, averaging $2.02 \mu \mathrm{mol} / \mathrm{L}$. Values obtained were consistent with past data for the epilimnion of Douglas Lake ( $\mathrm{R}$. Glover, personal communication) in that both $\mathrm{NO}_{3}$ and $\mathrm{PO}_{4}$ concentrations were very low during midsummer.

Algal biomass, assessed either as chlorophyll $a$ or as total biovolume of all algal taxa (Table 1), showed approximately 100 -fold variation according to nutrient treatment. Mean chlorophyll $a$ values ranged from 0.17 $\mu \mathrm{g} / \mathrm{cm}^{2}$ for pots without added nutrients to $15.7 \mu \mathrm{g} /$ $\mathrm{cm}^{2}$ for pots with $\mathrm{P}$ at $0.05 \mathrm{~mol} / \mathrm{L}+\mathrm{N}$ at $0.5 \mathrm{~mol} / \mathrm{L}$. Addition of $\mathbf{P}$ alone $(0.05$ or $0.5 \mathrm{~mol} / \mathrm{L})$ caused a significant increase in chlorophyll $a(P<.001)$. Addition of $\mathrm{N}$ alone produced a (nonsignificant) 1.5- to twofold increase in chlorophyll $a$ over control pots. Chlorophyll $a$ on all four $\mathrm{N}+\mathrm{P}$ treatments showed significant $(P<.001)$ increases over control levels; the increase was maximal on pots containing $\mathrm{N}$ at $0.5 \mathrm{~mol} / \mathrm{L}$. Chlorophyll $a$ values on $\mathrm{N}+\mathrm{P}$ pots with $\mathrm{P}$ at $0.5 \mathrm{~mol} / \mathrm{L}$ were significantly lower than on $\mathrm{N}+\mathrm{P}$ pots with $\mathrm{P}$ at $0.05 \mathrm{~mol} / \mathrm{L}(P<.001)$.

Similar results were obtained for total periphyton 

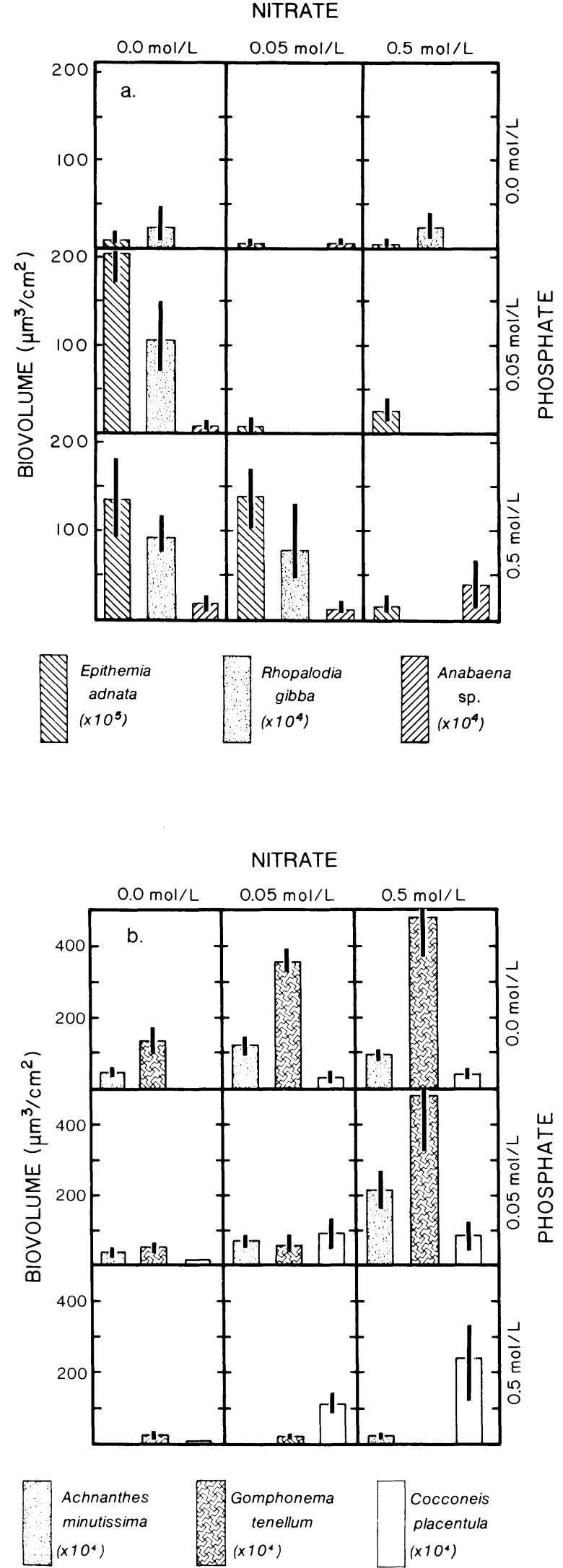

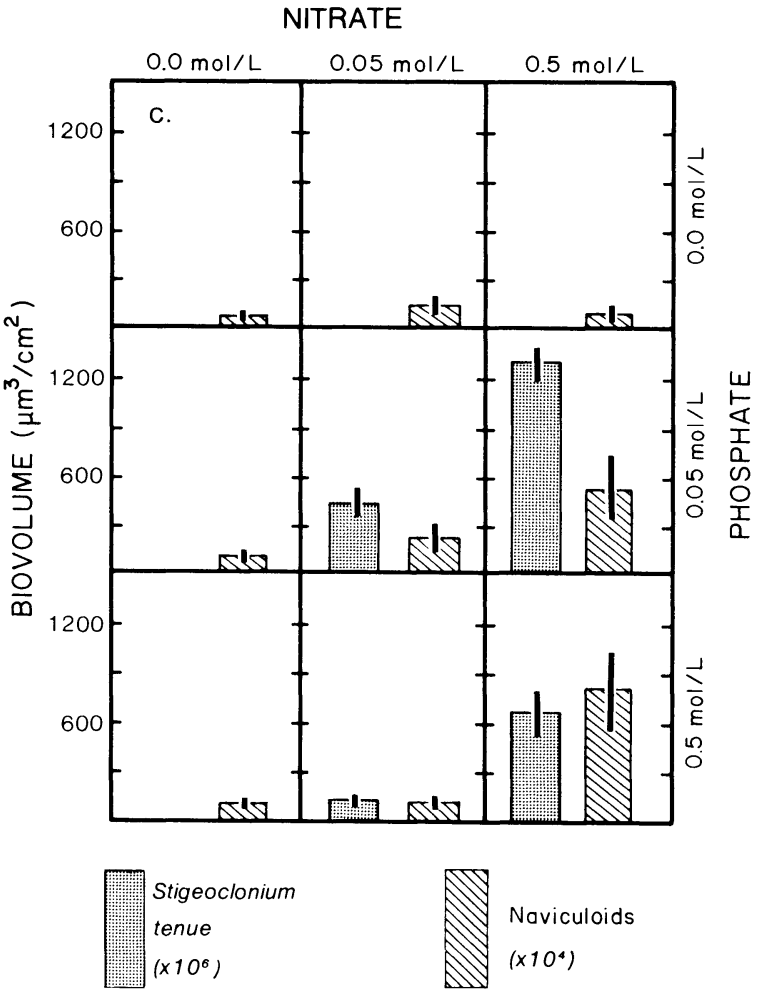

FIG. 3. Biovolumes of eight taxa on pots containing nine combinations of $\mathrm{N}$ and $\mathrm{P}(\bar{x} \pm \mathrm{SE}, n=4)$. Taxa with significant growth responses to $\mathrm{P}$ alone and to $\mathrm{N}$ alone are shown in (a) and (b), respectively. Two taxa (c) responded significantly only when $\mathrm{N}$ and $\mathrm{P}$ were supplied together.

biovolume. Reduced growth at $\mathrm{N}+\mathrm{P}$ at $0.5 \mathrm{~mol} / \mathrm{L}$ relative to $\mathrm{N}+\mathrm{P}$ at $0.05 \mathrm{~mol} / \mathrm{L}$ was again evident $(P<$ $.001)$. A slight increase in biovolume again accompanied the addition of $\mathrm{N}$ alone $(P<.05)$.

Algal taxa that experienced significant growth enhancement in response to particular nutrient additions are shown in Fig. 3a-c. Three general types of growth responses were distinguished. Three taxa were capable of significantly enhanced growth with $\mathrm{P}$ alone added (Fig. 3a). This was determined by comparing the two $\mathrm{P}$ treatments $(n=8)$ with the control pots $(n=4)$. Three species experienced significant growth in response to $\mathrm{N}$ addition $(n=8)$ as compared to controls $(n=4)$ (Fig. 3b). Finally, two taxa (Fig. 3c) responded significantly to additions of $\mathrm{N}+\mathrm{P}(n=16)$ compared to growth when either nutrient was added alone $(n=$ $8)$.

Of the three taxa that responded to $\mathrm{P}$ alone, two were large diatoms (Epithemia adnata [Kütz.] Bréb. and Rhopalodia gibba [Ehr.] O. Müll.), and one was a filamentous blue-green (Anabaena sp.). Epithemia experienced a 15 - to 25 -fold increase on pots with $\mathrm{P}$ at 0.05 or $0.5 \mathrm{~mol} / \mathrm{L}$ compared to control pots $(P<.01)$, 
and was clearly the dominant species present, comprising 68.6 and $58.8 \%$ of total biovolume, respectively. Although the growth of Epithemia on pots containing $\mathrm{P}$ at $0.5 \mathrm{~mol} / \mathrm{L}+\mathrm{N}$ at $0.05 \mathrm{~mol} / \mathrm{L}$ remained high, its contribution to total biovolume declined to $8.6 \%$. Rhopalodia also responded significantly to $\mathrm{P}$ addition $(P<.05)$, but was less abundant than Epithem$i a$, representing 3.5 and $4.7 \%$ of total biovolume on the pots with $\mathrm{P}$ at 0.05 and $0.5 \mathrm{~mol} / \mathrm{L}$, respectively. Anabaena increased significantly $(P<.001)$ from $7.8 \times 10^{3} \mu \mathrm{m}^{3} / \mathrm{cm}^{2}$ on control pots to $1.0 \times 10^{5} \mu \mathrm{m}^{3} /$ $\mathrm{cm}^{2}$ and $1.8 \times 10^{6} \mu^{3} / \mathrm{cm}^{2}$ on pots with $\mathrm{P}$ at 0.05 and $0.5 \mathrm{~mol} / \mathrm{L}$, respectively.

Achnanthes minutissima Kütz., a diminutive diatom, increased two- to threefold in biovolume when $\mathrm{N}$ was added alone $(P<.01)$, with a maximum abundance of $1.3 \times 10^{6} \mu \mathrm{m}^{3} / \mathrm{cm}^{2}(8.6 \%$ of total biovolume $)$ on pots with $\mathrm{N}$ at $0.05 \mathrm{~mol} / \mathrm{L}$. Gomphonema tenellum Kütz. also achieved significantly higher growth on pots with $\mathrm{N}$ added alone $(P<.01)$, with $4.9 \times 10^{6} \mu \mathrm{m}^{3} / \mathrm{cm}^{2}$ ( $36.3 \%$ of total biovolume) on the $0.5 \mathrm{~mol} / \mathrm{L}$ substrates. The diatom Cocconeis placentula Ehr., found very infrequently on substrates without $\mathrm{N}$, increased significantly $(P<.01)$ in response to $\mathrm{N}$ addition, but achieved a maximum relative abundance of only $2.5 \%$ of total biovolume on the substrates with $\mathrm{N}$ at $0.5 \mathrm{~mol} / \mathrm{L}$.

The three taxa that experienced increased growth with $\mathrm{P}$ addition (Epithemia, Rhopalodia, Anabaena) experienced no further growth when $\mathrm{N}$ was also added. Of the three taxa that responded to $\mathrm{N}$ addition, only Cocconeis showed significant further growth $(P<.01)$ when $P$ was also supplied. Both Achnanthes and Gomphonema were significantly inhibited on the pots with $\mathrm{P}$ at $0.5 \mathrm{~mol} / \mathrm{L}$ relative to those with $\mathrm{P}$ at $0.05 \mathrm{~mol} / \mathrm{L}$ $(P<.001)$.

The increase in total biovolume on the $\mathrm{N}+\mathrm{P}$ pots was due almost entirely to the growth response of the filamentous green alga Stigeoclonium tenue (Ag.) Kütz. Stigeoclonium represented $1.7 \times 10^{6} \mu \mathrm{m}^{3} / \mathrm{cm}^{2}$ on control pots $(7.7 \%$ of total biovolume) and reached its maximum growth of $1.3 \times 10^{9} \mu \mathrm{m}^{3} / \mathrm{cm}^{2}(98.7 \%$ of total biovolume) on pots with $\mathrm{P}$ at $0.05 \mathrm{~mol} / \mathrm{L}+\mathrm{N}$ at $0.5 \mathrm{~mol} / \mathrm{L}$. Stigeoclonium clearly dominated the other $\mathrm{P}+\mathrm{N}$ treatments as well, with $98.1,96.4$, and $87.3 \%$ of total biovolume on pots with $\mathrm{P}+\mathrm{N}$ at $0.05 \mathrm{~mol} / \mathrm{L}+$ $0.05 \mathrm{~mol} / \mathrm{L}, 0.5 \mathrm{~mol} / \mathrm{L}+0.5 \mathrm{~mol} / \mathrm{L}$, and $0.5 \mathrm{~mol} / \mathrm{L}+$ $0.05 \mathrm{~mol} / \mathrm{L}$, respectively. Whereas Stigeoclonium did not respond to either $\mathrm{N}$ or $\mathrm{P}$ added alone, its growth on the $\mathrm{N}+\mathrm{P}$ additions was significant for both $\mathrm{N}(P<$ $.001)$ and $\mathrm{P}(P<.01)$. Naviculoid diatoms (not identified to species), increased 10 -fold on pots with $\mathrm{N}$ at $0.5 \mathrm{~mol} / \mathrm{L}+\mathrm{P}$ at $0.5 \mathrm{~mol} / \mathrm{L}$, compared to control pots, but reached maximum relative abundances of just $1.3 \%$ of total biovolume. The naviculoids, like Stigeoclonium, did not experience significant growth enhancement when either $\mathrm{N}$ or $\mathrm{P}$ was added alone, but did respond to both $\mathrm{N}(P<.01)$ and $\mathrm{P}(P<.05)$ when the two nutrients were added together. The greater the amount of $\mathrm{N}$ contained in the $\mathrm{N}+\mathrm{P}$ pots, the more pronounced was the growth response for both taxa.

Centric diatoms (chiefly Cyclotella sp.) were abundant on all pots, ranging between 1.1 and $3.8 \times 10^{5}$ $\mu \mathrm{m}^{3} / \mathrm{cm}^{2}$, but showed no significant differences among treatments. Other taxa among the 46 enumerated were found sporadically, and in generally lower densities than those named above.

\section{Discussion}

\section{Algal response to $P$ addition}

Of the three taxa that responded positively to the addition of $\mathrm{P}$ alone, Anabaena sp. possessed heterocysts and is presumed to be capable of fixing nitrogen (Rhee and Lederman 1983); Rhopalodia gibba was first described to possess endosymbiotic blue-green algae by Drum and Pankratz (1965), and the ability of this endosymbiont to fix nitrogen was shown later by Floener and Bothe (1980); and Geitler (1977) described spherical bodies in Epithemia zebra $(=E$. adnata) and suspected that they were symbiotic blue-green algae. Observations with transmission electron microscopy confirm the presence of endosymbiotic blue-green algae in specimens of $E$. adnata from the P pots (Lowe et al. 1984).

The increase in algal biovolume on the $\mathrm{P}$ pots relative to control pots is contributed by these three taxa alone. If they are removed from the analysis, the adjusted biovolumes for the $\mathrm{P}$ at 0.05 and $0.5 \mathrm{~mol} / \mathrm{L}$ and control pots are $8.2 \times 10^{6} \mu \mathrm{m}^{3} / \mathrm{cm}^{2}, 7.7 \times 10^{6} \mu \mathrm{m}^{3}$ $\mathrm{cm}^{2}$, and $8.0 \times 10^{6} \mu \mathrm{m}^{3} / \mathrm{cm}^{2}$, respectively, with no significant growth stimulation of taxa not suspected of fixing elemental nitrogen.

The decline in overall algal biovolume on pots with $\mathrm{P}$ at 0.5 compared to $0.05 \mathrm{~mol} / \mathrm{L}$ indicates an apparent inhibition of growth, particularly of some taxa (e.g., Stigeoclonium, Epithemia, Achnanthes, Gomphone$m a$ ). This inhibition is most reasonably ascribed either to an excess of phosphate (Rodhe 1948) or possibly to concurrent release from the pots of large amounts of potassium, which accompanied the phosphate as $\mathrm{K}_{2} \mathrm{HPO}_{4}$. Lehman's (1976) findings of significant growth inhibition of the planktonic chrysophytes Dinobryon cylindricum and D. sociale var. americanum when cultured at high levels of $\mathrm{K}_{2} \mathrm{HPO}_{4}$ compared with $\mathrm{Na}_{2} \mathrm{HPO}_{4}$ are consistent with the second possibility.

\section{Algal response to $N$ addition}

The low $\mathrm{NO}_{3}$ values for Douglas Lake and the growth response of Achnanthes, Gomphonema, and Cocconeis when $\mathrm{N}$ was supplied indicate that these taxa may have been $\mathrm{N}$ limited. A. minutissima is a common and frequently dominant member of the periphyton in a wide variety of situations (Allanson 1973, Brown and Austin 1973, Kuhn et al. 1981), and was inferred by Williams et al. (1973) to be nitrate limited relative to other species in Lake George, New York. In Stockner and Short- 


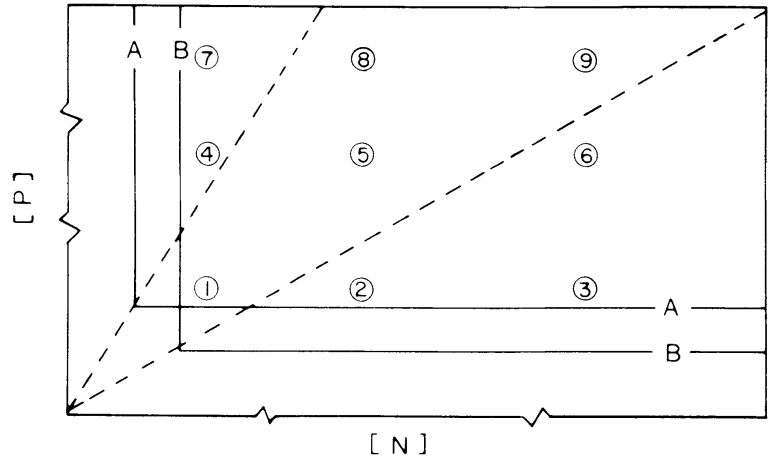

FIG. 4. Zero net-growth isoclines (ZNGI) are provided for two hypothetical periphyton species (A and B) as described in Discussion: Periphyton Species as Nutrient Specialists. The dotted lines denote their optimal N:P ratios. The placement of each of the nine nutrient treatments indicates its relative supplies of $\mathrm{N}$ and $\mathrm{P}$ (see also Fig. 1). 1: Control; 2: $\mathrm{N}$ at 0.05 $\mathrm{mol} / \mathrm{L} ; 3: \mathrm{N}$ at $0.5 \mathrm{~mol} / \mathrm{L} ; 4: \mathrm{P}$ at $0.05 \mathrm{~mol} / \mathrm{L} ; 5: \mathrm{P}$ at 0.05 $\mathrm{mol} / \mathrm{L}+\mathrm{N}$ at $0.05 \mathrm{~mol} / \mathrm{L} ; 6: \mathrm{P}$ at $0.05 \mathrm{~mol} / \mathrm{L}+\mathrm{N}$ at $0.5 \mathrm{~mol} /$ $\mathrm{L}$; 7: $\mathrm{P}$ at $0.5 \mathrm{~mol} / \mathrm{L} ; 8: \mathrm{P}$ at $0.5 \mathrm{~mol} / \mathrm{L}+\mathrm{N}$ at $0.05 \mathrm{~mol} / \mathrm{L}$; 9: $\mathrm{P}$ at $0.5 \mathrm{~mol} / \mathrm{L}+\mathrm{N}$ at $0.5 \mathrm{~mol} / \mathrm{L}$. The observed growth responses of Epithemia, Rhopalodia, and Anabaena were similar to growth predicted for species A. Growth of Achnanthes, Gomphonema, and Cocconeis resembled that for species $B$.

reed's (1978) study of periphyton in Carnation Creek, Vancouver Island, A. minutissima was a dominant species in stream troughs with no added nutrients or with added $\mathrm{NO}_{3}$, but was overgrown by other taxa in troughs with added $\mathrm{PO}_{4}$. Ecological preferences for particular nutrient concentrations are not well known for Gomphonema tenellum or Cocconeis placentula.

\section{Algal response to $N+P$}

The filamentous green alga Stigeoclonium tenue, the clear dominant in all combinations of $\mathrm{N}+\mathrm{P}$, has been ranked as the sixth most tolerant alga to organic enrichment (Palmer 1969). Organic enrichment usually provides large quantities of both $\mathrm{N}$ and $\mathrm{P}$. Considerable habitat modification by Stigeoclonium complicates the interpretation of growth stimulation of the naviculoid diatoms. Overgrowth by Stigeoclonium may also have reduced the abundance of Epithemia and Rhopalodia.

\section{Periphyton species as nutrient specialists}

A plausible explanation of the observed growth responses is shown in Fig. 4, modified from Smith's (1982) description of $\mathrm{N}: \mathrm{P}$ requirements of phytoplankton. The placement of the nine nutrient treatments in Fig. 4 is judged accurate only in their relative supply rates of $\mathrm{N}$ and P. Lines A and B denote the Zero Net Growth Isoclines (ZNGI) for two hypothetical periphyton species potentially competing for two essential resources (Tilman 1982). Optimal N:P requirements are shown as dotted lines for each. The amounts of available $\mathrm{N}$ and $\mathrm{P}$ should both decline over time as periphyton biomass and uptake increase. Further growth for a given species is curtailed when its ZNGI is reached, and may imply either $\mathrm{N}$ or $\mathrm{P}$ limitation, depending upon the portion of the ZNGI intercepted.

The increased growth of Achnanthes, Gomphonema, and Cocconeis on pots with added $\mathrm{N}$ suggests that their ZNGI's may be similar to that of species B. Although presumably $\mathrm{N}$ limited on the control pots, when $\mathrm{N}$ was supplied these taxa probably became $\mathrm{P}$ limited. Their increased growth is consistent with their being superior competitors for P.

Likewise, Epithemia, Rhopalodia, and Anabaena, which were P limited on the control pots, may have nutrient requirements more similar to species $\mathrm{A}$. Their considerable growth on the pots with added $\mathrm{P}$ appears to be the result of $\mathrm{N}$ fixation under otherwise $\mathrm{N}$-limiting conditions.

Stigeoclonium showed rapid growth on all pots with $\mathrm{N}+\mathrm{P}$, with $\mathrm{N}: \mathrm{P}$ ratios ranging over approximately two orders of magnitude. Francke and Den Oude (1983) have suggested that the $\mathrm{N}$ and $\mathrm{P}$ requirements of Stigeoclonium spp. are high relative to most algae, and the dominance of $S$. tenue in this study may well reflect the advantages of a filamentous growth form highly adapted to obtaining both light and nutrients in nutrient-enriched waters.

The higher biotic density of periphyton communities relative to the phytoplankton may accentuate the growth-limiting potential of other resources such as light and available attachment sites for many species. Despite the addition of two principal nutrients deemed critical to the growth of periphyton in Douglas Lake, only 8 of 46 taxa actually showed significantly enhanced growth. Because the overall community response to nutrient addition may thus be dependent upon the growth of a small number of species, an understanding of such indicator species can be critical to interpretations of overall growth as a bioassay of nutrient limitation.

\section{ACKNOWLEDGMENTS}

We wish particularly to thank Rebecca Glover for assistance with some of the nutrient analyses, and Peter Kilham, David Tilman, David White, and an anonymous reviewer for criticisms of the manuscript. The University of Michigan Biological Station provided generous technical assistance.

\section{Literature Cited}

Allanson, B. R. 1973. The fine structure of the periphyton of Chara sp. and Potamogeton natans from Wytham Pond, Oxford, and its significance to the macrophyte-periphyton model of R. G. Wetzel and H. L. Allen. Freshwater Biology 3:535-542.

Brown, S. D., and A. P. Austin. 1973. Diatom succession and interaction in littoral periphyton and plankton. Hydrobiologia 43:333-356.

Chapman, A. R. O., and J. S. Craigie. 1977. Seasonal growth in Laminaria longicruris: relations with dissolved inorganic nutrients and internal reserves of nitrogen. Marine Biology (Berlin) 40:197-205.

Chiaudani, G., and M. Vighi. 1975. Dynamics of nutrient limitations in six small lakes. Internationale Vereinigung für Theoretische und Angewandte Limnologie Verhandlungen 19:1319-1324. 
Droop, M. R. 1974. The nutrient status of algal cells in continuous culture. Journal of the Marine Biological Association of the United Kingdom 54:825-855.

Drum, R. W., and S. Pankratz. 1965. Fine structure of an unusual cytoplasmic inclusion in the diatom genus, Rhopalodia. Protoplasma 60:141-149.

Floener, L., and H. Bothe. 1980. Nitrogen fixation in Rhopalodia gibba, a diatom containing blue-greenish inclusions symbiotically. Pages 514-552 in W. Schwemmler and H. E. A. Schwenk, editors. Endocytobiology, endosymbiosis and cell biology, Volume I. Walter de Gruyter, Berlin, Germany.

Francke, J. A., and P. J. Den Oude. 1983. Growth of Stigeoclonium and Oedogonium species in artificial ammonium-N and phosphate-P gradients. Aquatic Botany 15: 375-380.

Geitler, L. 1977. Zur Entwicklungsgeschichte der Epithemiaceen Epithemia, Rhopalodia, and Denticula (Diatomophyceae) und ihre vermutlich symbiotischen Sphäroidkörper. Plant Systematics and Evolution 128:259-275.

Gerhart, D. Z., and G. E. Likens. 1975. Enrichment experiments for determining nutrient limitation: four methods compared. Limnology and Oceanography 20:649-653.

Glass, G. E., editor. 1973. Bioassay techniques and environmental chemistry. Ann Arbor Science, Ann Arbor, Michigan, USA.

Harlin, M. M., and B. Thorne-Miller. 1981. Nutrient enrichment of seagrass beds in a Rhode Island coastal lagoon. Marine Biology (Berlin) 65:221-229.

Holm-Hansen, O., C. J. Lorenzen, R. W. Holmes, and J. D. H. Strickland. 1965. Fluorometric determination of chlorophyll. Journal du Conseil Conseil International pour l'Exploration de la Mer 30:3.

Komarkova, J. 1979. In situ tests using phytoplankton. Pages 193-204 in P. Marvan, S. Pribil, and O. Lhotsky, editors. Algal assays and monitoring eutrophication. E. Schweizerbart'sche Verlagsbuchhandlungen, Stuttgart, Germany.

Kratzer, C. R., and P. L. Brezonik. 1981. A Carlson-type trophic state index for nitrogen in Florida lakes. Water Resources Bulletin 17:713-714.

Krewer, J. A., and H. W. Holm. 1982. The phosphoruschlorophyll $a$ relationship in periphytic communities in a controlled ecosystem. Hydrobiologia 94:173-176.

Kuhn, D. L., J. L. Plafkin, J. Cairns, Jr., and R. L. Lowe. 1981. Qualitative characterization of aquatic environments using diatom life-form strategies. Transactions of the American Microscopical Society 100:165-182.

Lehman, J. T. 1976. Ecological and nutritional studies on Dinobryon Ehrenb.: Seasonal periodicity and the phosphate toxicity problem. Limnology and Oceanography 21:646658.

Lowe, R. L., B. H. Rosen, and G. W. Fairchild. 1984. Endosymbiotic blue-green algae in freshwater diatoms: an advantage in nitrogen poor habitats. Journal of Phycology 20 (supplement): 24 .

Marcus, M. D. 1980. Periphyton community response to chronic nutrient enrichment by a reservoir discharge. Ecology 61:387-399.

Marvan, P., S. Pribil, and O. Lhotsky, editors. 1979. Algal assays and monitoring eutrophication. E. Schweizerbart'sche Verlagsbuchhandlungen, Stuttgart, Germany.

Middlebrooks, E. J., D. H. Falkenborg, and T. E. Maloney, editors. 1976. Biostimulation and nutrient assessment. Ann Arbor Science, Ann Arbor, Michigan, USA.

Moss, B. 1981. The composition and ecology of periphyton communities in freshwaters. II. Inter-relationships between water chemistry, phytoplankton populations and periphyton populations in a shallow lake and associated experimental reservoirs ('Lund Tubes'). British Phycological Journal 16:59-76.

Palmer, C. M. 1969. A composite rating of algae tolerating organic population. Journal of Phycology 5:78-82.

Peterson, B. J., J. E. Hobbie, T. L. Corliss, and K. Kriet. 1983. A continuous-flow periphyton bioassay: tests of nutrient limitation in a tundra stream. Limnology and Oceanography 28:583-591.

Rhee, G.-Y. 1978. Effects of N:P atomic ratios and nitrate limitation on algal growth, cell composition and nitrate uptake. Limnology and Oceanography 23:10-25.

Rhee, G.-Y., and T. C. Lederman. 1983. Effects of nitrogen sources on P-limited growth of Anabaena flos-aquae. Journal of Phycology 19:179-185.

Rodhe, W. 1948. Environmental requirements of freshwater planktonic algae. Experimental studies of the ecology of phytoplankton. Symbolae Botanicae Upsaliensis 10:1-149.

Schelske, C. L., M. Simmons, and L. E. Feldt. 1975. Phytoplankton responses to phosphorus and silica enrichments in Lake Michigan. Internationale Vereinigung für Theoretische und Angewandte Limnologie Verhandlungen 19:91 1921.

Schindler, D. 1977. Evolution of phosphorus limitation in lakes. Science 195:260-262.

Sladeckova, A. 1979. Periphyton assays in situ. Pages 205209 in P. Marvan, S. Pribil, and O. Lhotsky, editors. Algal assays and monitoring eutrophication. E. Schweizerbart'sche Verlagsbuchhandlungen, Stuttgart, Germany.

Smith, V. H. 1982. The nitrogen and phosphorus dependence of algal biomass in lakes: an empirical and theoretical analysis. Limnology and Oceanography 27:1 101-1112.

Stevenson, R. J., and E. F. Stoermer. 1982. Abundance patterns of diatoms on Cladophora in Lake Huron with respect to a point source of wastewater treatment plant effluent. Journal of Great Lakes Research 8:184-195.

Stockner, J. G., and K. R. S. Shortreed. 1978. Enhancement of autotrophic production by nutrient addition in a coastal rainforest stream on Vancouver Island. Journal of the Fisheries Research Board of Canada 35:28-34.

Storch, T. A., and G. A. Dietrich. 1979. Seasonal cycling of algal nutrient limitation in Chatauqua Lake, New York. Journal of Phycology 15:399-405.

Tilman, D. 1982. Resource competition and community structure. Monographs in Population Biology 17.

Tilman, D., S. S. Kilham, and P. Kilham. 1982. Phytoplankton community ecology: The role of limiting nutrients. Annual Review of Ecology and Systematics 13:349372.

Williams, S. L., E. M. Colon, R. Kohlberger, and N. L. Clesceri. 1973. Response of plankton and periphyton diatoms in Lake George (N.Y.) to the input of nitrogen and phosphorus. Pages 441-466 in G. E. Glass, editor. Bioassay techniques and environmental chemistry. Ann Arbor Science, Ann Arbor, Michigan, USA.

Wuhrmann, K., and E. Eichenberger. 1974. Experiments on the effects of inorganic enrichment of rivers on periphyton primary production. Internationale Vereinigung für Theoretische und Angewandte Limnologie Verhandlungen 19: 2028-2034.

Zevenboom, W., A. Bij de Vaate, and L. R. Mur. 1982. Assessment of factors limiting growth rate of Oscillatoria agardhii in hypertrophic Lake Wolderwijd, 1978, by use of physiological indicators. Limnology and Oceanography 27: 39-52. 